\title{
FISH COMMUNITIES OF FIVE DRINKING WATER RESERVOIRS IN THE MORAVA RIVER BASIN
}

\author{
Pavel Jurajda ${ }^{1}$, Michal Janáč , Kevin Roche ${ }^{1}$, Libor Mikl¹, Luděk Šlapanský ${ }^{1}$, \\ Ivo Krechler ${ }^{2}$,Zdeněk Adámek ${ }^{1}$, Zdenka Jurajdováㄹ, Karel Halačka ${ }^{1}$ \\ ${ }^{1}$ Institute of Vertebrate Biology of the Czech Academy of Sciences v.v.i., Květná 8, 60365 Brno, Czech Republic \\ ${ }^{2}$ Morava River Authority, Dřevařská 11,602 00 Brno, Czech Republic
}

\begin{abstract}
JURAJDA PAVEL, JANÁČ MICHAL, ROCHE KEVIN, MIKL LIBOR, ŠLAPANSKÝ LUDĚK, KRECHLER IVO, ADÁMEK ZDENĚK, JURAJDOVÁ ZDENKA, HALAČKA KAREL. 2018. Fish Communities of Five Drinking Water Reservoirs in the Morava River Basin. Acta Universitatis Agriculturae et Silviculturae Mendelianae Brunensis, 66(3): 655-663.

While fish communities have been studied in Czech reservoirs for decades, monitoring has increased since implementation of the EU Water Framework Directive (2000/60/EC). Despite this, many smaller drinking water reservoirs have yet to be surveyed. Between May and July 2016, we undertook a pilot-study examining the fish communities of five Moravian reservoirs (Ludkovice, Bojkovice, Hubenov, Nová Řiše and Landštejn). Fish were sampled using boat electrofishing along the littoral zone and Nordic gill nets in the pelagic zone. Both methods were evaluated separately and combined as CPUE and relative abundance and biomass (\%). Nineteen fish species and one hybrid were recorded, with roach Rutilus rutilus dominating overall by abundance, but carp Cyprinus carpio, pike Esox lucius and wels Silurus glanis dominating by biomass in electrofishing samples. Predatory species represented up to $60 \%$ of biomass in the combined sample, with an F/C index ranging from 0.5-3, implying a high abundance of predators. Electrofishing tended to underestimate the abundance of bleak and ruffe, while gill nets underestimated the biomass of predatory species. In some reservoirs, the abundance of pike and wels was high (though it is difficult to say if these fish were stocked or the result of natural reproduction). In others (e.g. Landštejn), zander Sander lucioperca were not registered by either sampling method, despite intensive stocking. Overall, gill netting alone appears inadequate for gaining a true picture of the fish community in reservoirs and we suggest a combination of electrofishing and gill netting in future.
\end{abstract}

Keywords: biomanipulation, predator stocking, reservoir fish assemblage, sampling strategy

\section{INTRODUCTION}

Reservoirs are man-made aquatic habitats that can serve multiple purposes, including sources of electrical energy, flood control, drinking water supply, irrigation or recreation. Of the 120 reservoirs in Czechia, 47 are registered as drinking water supply reservoirs and, as such, undergo specific management regimes (e.g. no recreational activities, prohibited angling, fisheries management) in order to ensure high water quality. In addition to limited public access and a ban on recreational activities, angling is prohibited and fish stocks are managed to reduce the numbers of fish that can negatively affect water quality mostly roach Rutilus rutilus and common bream Abramis brama (e.g. Lathrop et al., 2002; Mehner et al., 2002), generally by removal and/or the stocking of predatory species such as pike Esox lucius, wells Silurus glanis or zander Sander lucioperca.

Although fish communities have been studied in some Czech reservoirs for many years (Kubečka, 1993), monitoring has increased greatly since 
implementation of the EU Water Framework Directive (2000/60/EC), which specifically requires a wide-scale assessment of the ecological status of reservoirs (Blabolil et al., 2014). While some Czech reservoirs have been monitored for decades, e.g. Římov (Vašek et al., 2006; Prchalová et al.; 2009; Ríha et al., 2009), Klíčava (Pivnička, 1992) or Lipno (Vostradovský and Tichý, 1999), many smaller drinking water reservoirs have yet to be surveyed, particularly in the Morava river basin.

The aim of this pilot study was to provide base line data for assessing the fish communities of five previously unmonitored or partially monitored drinking water reservoirs. In doing so, we also aim to evaluate the impacts of predatory fish stocking on the fish assemblages and, ultimately, on reservoir water quality.

\section{MATERIALS AND METHODS}

\section{Study area}

Five reservoirs were examined in this study, Ludkovice, Bojkovice, Hubenov, Nová Říše and Landštejn (Tab. I), all of which were constructed as drinking water resources and as a means of stabilising downstream river discharge. Two of the reservoirs (Bojkovice and Ludkovice) are situated in the Bílé Karpaty mountains in the eastern part of the Morava river basin, while the other three (Landštejn, Hubenov, Nová Říše) are situated in Vysočina in the western part of the basin.
Bojkovice and Ludkovice are both small eutrophic reservoirs ( $<20 h a)$, receiving high nutrient and organic input from the sewage treatment plants of adjacent villages. The larger Landštejn, Hubenov and Nová Říše reservoirs are situated in forested countryside and receive much lower nutrient inputs. Fisheries management in all the reservoirs is limited to supportive stocking of predatory fish species; mainly pike, zander, asp Leuciscus aspius and wells. No other biomanipulation activities (e.g. large-scale removal of cyprinids) have been undertaken to date.

\section{Fish sampling}

Sampling used in this study followed the routine monitoring schedule of the Morava River Authority, with an extension of the sample area and number of gill nets exposed. Fish (1+ and older) were sampled along the shoreline during daylight from late May to early July 2016 by boat electrofishing (one hand-held anode, EFKO FEG 13000, Honda $13 \mathrm{~kW}, 300 \mathrm{~V}, 60 \mathrm{~A}, 50-80 \mathrm{~Hz}$ ), the stunned fish being collected with a $5 \mathrm{~mm}$ mesh hand net. The length of each stretch sampled (depending on reservoir size and availability of shallow shoreline) was noted and the number of individuals caught calculated as catch per unit effort (CPUE), i.e. individuals per 100 m stretch (see Kubečka et al., 2010). Standard benthic (fa. Pokorný s.r.o., CR; 12 panels, $1.5 \mathrm{~m}$ high) and pelagic (12 panels, $3.0 \mathrm{~m}$ high) multi-mesh gill nets were exposed overnight (number of gill nets depending on reservoir size and feasibility). As

I: Main characteristics of the five drinking water reservoirs sampled in 2016.

\begin{tabular}{|c|c|c|c|c|c|}
\hline Characteristic/Reservoir & Hubenov & Bojkovice & Landštejn & Ludkovice & Nová Říše \\
\hline Stream & $\begin{array}{c}\text { Maršovský } \\
\text { brook }\end{array}$ & Kolelač & Pstruhovec & $\begin{array}{c}\text { Ludkovický } \\
\text { brook }\end{array}$ & Řečice \\
\hline GIS coordinates & $\begin{array}{l}49^{\circ} 23^{\prime} 40^{\prime \prime} \mathrm{N} \\
15^{\circ} 29^{\prime} 7^{\prime \prime} \mathrm{E}\end{array}$ & $\begin{array}{l}49^{\circ} 3^{\prime} 10^{\prime \prime} \mathrm{N} \\
17^{\circ} 50^{\prime} 52^{\prime \prime} \mathrm{E}\end{array}$ & $\begin{array}{l}49^{\circ} 1{ }^{\prime} 28^{\prime \prime} \mathrm{N} \\
15^{\circ} 14^{\prime} 28^{\prime \prime} \mathrm{E}\end{array}$ & $\begin{array}{l}49^{\circ} 7^{\prime} 28^{\prime \prime} \mathrm{N} \\
17^{\circ} 43^{\prime} 45^{\prime \prime} \mathrm{E}\end{array}$ & $\begin{array}{l}49^{\circ} 9^{\prime} 19^{\prime \prime} \mathrm{N} \\
15^{\circ} 32^{\prime} 40^{\prime \prime} \mathrm{E}\end{array}$ \\
\hline Put into operation & 1972 & 1966 & 1973 & 1968 & 1985 \\
\hline Total capacity (Mill. m³) & 3.385 & 0.965 & 3.266 & 0.690 & 3.090 \\
\hline Catchment area $\left(\mathrm{Km}^{2}\right)$ & 19.9 & 13.8 & 12.7 & 13.1 & 21.3 \\
\hline Meters above sea-level & 520 & 320 & 570 & 285 & 555 \\
\hline Max depth & 19 & 16 & 23 & 15 & 20 \\
\hline Flooded area & 55.0 & 15.5 & 40.5 & 12.5 & 53.5 \\
\hline Average depth & 6.2 & 6.2 & 8.9 & 5.5 & 5.8 \\
\hline Chlorophyll-a ( $\mu \mathrm{g} / \mathrm{L})$ & 18 & 17 & 13 & 22 & 8 \\
\hline Av. summer water temp. $\left({ }^{\circ} \mathrm{C}\right)$ & $20-24^{\circ} \mathrm{C}$ & $20-27^{\circ} \mathrm{C}$ & $19-25^{\circ} \mathrm{C}$ & $21-26^{\circ} \mathrm{C}$ & $19-24^{\circ} \mathrm{C}$ \\
\hline Electrofishing sites (m) & 3190 & 1567 & 1897 & 1488 & 1687 \\
\hline Benthic/pelagic gill nets (n) & $8 / 5$ & $5 / 5$ & $11 / 5$ & $5 / 5$ & $8 / 5$ \\
\hline Species stocked 2011-2015 & $\begin{array}{c}\text { zander, wells, } \\
\text { asp }\end{array}$ & $\begin{array}{l}\text { pike, zander, } \\
\text { wells }\end{array}$ & $\begin{array}{l}\text { pike, zander, } \\
\text { wells, asp }\end{array}$ & $\begin{array}{l}\text { pike, zander, } \\
\text { wells }\end{array}$ & $\begin{array}{l}\text { pike, zander, } \\
\text { wells, asp }\end{array}$ \\
\hline
\end{tabular}


with electrofishing, the number of $1+$ and older fish caught were calculated as CPUE (i.e. individuals per 1 net). The results were also calculated as relative abundance and biomass (in \%), both separately and with electrofishing and gill net data combined. All fish were determined to species, individually measured (standard length, SL) and weighed (to the nearest $\mathrm{g}$ ) and released back to the water. The F/C ratio was calculated as the relationship between biomass of non-predatory fish (i.e. planktivorous, benthivorous species (F) and that of predatory fish (C). The F/C ratio is a simple expression of fish community balance in natural waterbodies. Values between 3 and 6 indicate an optimal ratio, while values $>10$ demonstrate undesirable fish community conditions with a strong prevalence of non-predatory fish (Holčík and Hensel, 1972).

\section{RESULTS}

A total of 5971 fish ( $\geq 1$ year), comprising 19 species from six families and one cyprinid hybrid, were caught during surveying in 2016 (Tab. II). Roach were clearly the most abundant species in all reservoirs, occasionally contributing $>60 \%$ of abundance, with perch Perca fluviatilis second most abundant in all reservoirs except Ludkovice, where bleak Alburnus alburnus (13\%) and common bream Abramis brama (11\%) were more common (Tab. II). While perch represented $26 \%$ of fish caught in Landštejn, numbers were lower at all other sites, and especially so at the highly eutrophic Bojkovice reservoir, where relative abundance was only $5 \%$ (Tab. II). Surprisingly, common bream relative abundance was relatively low in all reservoirs except Bojkovice, where it represented $26 \%$ of fish abundance. Predatory species (pike, zander, asp, wells and eel Anguila anguila) abundance was uniformly low, ranging from $2-4 \%$ (Tab. II).

Relative abundance (CPUE) showed marked differences between reservoirs (Figs. 1, 2). Highest gill net CPUE was recorded at Landštejn, where roach and perch were caught most often, followed by Ludkovice, where high numbers of bleak were caught (Fig. 1). In comparison, highest electrofishing CPUE was at Ludkovice, the catch

II: Relative abundance (\%) and biomass (\%) of fish species recorded in five drinking water reservoirs monitored in 2016.

\begin{tabular}{|c|c|c|c|c|c|c|c|c|c|c|c|}
\hline \multirow[b]{2}{*}{ Species } & \multirow[b]{2}{*}{ Scientific name } & \multicolumn{2}{|c|}{ Hubenov } & \multicolumn{2}{|c|}{ Bojkovice } & \multicolumn{2}{|c|}{ Landštejn } & \multicolumn{2}{|c|}{ Ludkovice } & \multicolumn{2}{|c|}{ Nová Říše } \\
\hline & & $\begin{array}{l}\text { ind. } \\
(\%)\end{array}$ & $\begin{array}{l}\mathrm{kg} \\
(\%)\end{array}$ & $\begin{array}{l}\text { ind. } \\
(\%)\end{array}$ & $\begin{array}{l}\mathrm{kg} \\
(\%)\end{array}$ & $\begin{array}{l}\text { ind. } \\
(\%)\end{array}$ & $\begin{array}{l}\mathrm{kg} \\
(\%)\end{array}$ & $\begin{array}{l}\text { ind. } \\
(\%)\end{array}$ & $\begin{array}{l}\mathrm{kg} \\
(\%)\end{array}$ & $\begin{array}{l}\text { ind. } \\
(\%)\end{array}$ & $\begin{array}{l}\mathrm{kg} \\
(\%)\end{array}$ \\
\hline Roach & Rutilus rutilus & 58.3 & 8.1 & 63.6 & 5.4 & 54.4 & 12.9 & 61.5 & 16.5 & 50.9 & 19.6 \\
\hline Bream & Abramis brama & 13.6 & 21.5 & 25.9 & 7.8 & 0.3 & 1.2 & 11.3 & 18.9 & 7.4 & 8.8 \\
\hline Rudd & $\begin{array}{l}\text { Scardinius } \\
\text { erythrophthalmus }\end{array}$ & 2.4 & 0.6 & 1.9 & 3.0 & 12.4 & 4.0 & 3.3 & 1.7 & 9.2 & 6.2 \\
\hline Carp & Cyprinus carpio & 1.6 & 31.5 & 0.6 & 47.0 & 1.2 & 30.8 & & & & \\
\hline Perch & Perca fluviatilis & 17.3 & 3.2 & 5.3 & 0.7 & 26.4 & 7.9 & 9.4 & 3.8 & 16.9 & 5.5 \\
\hline Pike & Esoxlucius & 3.3 & 22.9 & 0.9 & 13.0 & 3.0 & 17.7 & 0.7 & 18.0 & 2.1 & 9.6 \\
\hline Wells & Silurus glanis & 0.1 & 0.3 & 0.3 & 17.1 & 1.0 & 23.7 & 0.3 & 25.6 & 0.6 & 45.4 \\
\hline Zander & Sanderlucioperca & 0.1 & 0.4 & 0.9 & 4.5 & & & 0.1 & 0.7 & 1.2 & 2.6 \\
\hline Asp & Leuciscus aspius & & & 0.4 & 1.6 & & & & & 0.6 & 1.7 \\
\hline Ruffe & $\begin{array}{l}\text { Gymnocephalus } \\
\text { cernuus }\end{array}$ & 2.2 & 0.1 & & & 0.7 & $<0.1$ & & & 7.3 & 0.3 \\
\hline Bleak & Alburnus alburnus & & & & & 0.1 & $<0.1$ & 13.0 & 10.6 & & \\
\hline Eel & Anguilla anguilla & & & & & & & 0.3 & 4.1 & & \\
\hline Nase & $\begin{array}{l}\text { Chondrostoma } \\
\text { nasus }\end{array}$ & 0.1 & 0.4 & & & & & & & & \\
\hline $\begin{array}{l}\text { Grass } \\
\text { Carp }\end{array}$ & $\begin{array}{l}\text { Ctenopharyngodon } \\
\text { idella }\end{array}$ & 0.2 & 10.0 & & & & & & & & \\
\hline Gudgeon & Gobio gobio & 0.1 & $<0.1$ & & & & & & & & \\
\hline Chub & Squalius cephalus & 0.4 & 1.1 & & & & & & & & \\
\hline $\begin{array}{l}\text { Stone } \\
\text { Moroko }\end{array}$ & $\begin{array}{l}\text { Pseudorasbora } \\
\text { parva }\end{array}$ & 0.1 & $<0.1$ & & & & & & & & \\
\hline $\begin{array}{l}\text { Spined } \\
\text { Loach }\end{array}$ & $\begin{array}{l}\text { Cobitis } \\
\text { elongatoides }\end{array}$ & & & & & 0.1 & $<0.1$ & & & 3.2 & 0.3 \\
\hline Tench & Tinca tinca & & & & & 0.1 & 1.6 & & & & \\
\hline Hybrid & & 0.2 & $<0.1$ & 0.2 & $<0.1$ & 0.2 & 0.1 & 0.1 & 0.2 & 0.8 & 0.3 \\
\hline
\end{tabular}


mainly comprising roach, while Landštejn had the lowest electrofishing CPUE of all (Fig. 2). Both Hubenov and Nová Říše displayed low CPUE, whether by gill net or electrofishing. Landštejn also had the highest biomass CPUE by gill net, and a close second (Bojkovice first) by electrofishing (Figs. 3, 4). In all cases (but especially at Landštejn and Bojkovice), biomass species composition was dominated by common carp Cyprinus carpio, wells and pike, species that were generally missed in gill nets samples (Figs. 3, 4).

While cyprinids (followed by perch) dominated the catch by relative abundance at all reservoirs (Fig. 5), relative biomass composition differed markedly between reservoirs (Fig. 6), with cyprinids dominating at Hubenov (73\%) but predatory species dominating at Nová Říše (65\%). Common carp were registered in three of the five reservoirs (Hubenov, Bojkovice, Landštejn), but at low abundance $(<2 \%)$; by biomass, however, they represented between 27 and $47 \%$ of total biomass caught (Tab. II). Of the predatory species, only pike and wells were registered at all five reservoirs, with pike dominating by biomass at Hubenov and wells at Ludkovice and Nová Říše (Tab. II). Overall, pike abundance ranged between 0.7 and $3 \%$, but contributed between 10 and $23 \%$ by biomass. Wells abundance ranged between 0.1 and $1 \%$, but reached $45 \%$ by biomass at Nová Říše (Tab. II).

The highest F/C ratio (3) was observed at Hubenov and the lowest (0.5) at Nová Říše. At Ludkovice and Nová Říše in particular, F/C ratios were biased by the occurrence of large wells (Tab. II). All F/C ratios were lower than the recommended optimal range of 3-6, indicating an overly abundant predator population (Holčík and Hensel, 1972).

\section{DISCUSSION}

The fish assemblage at all reservoirs in this study corresponded with the "stable cyprinid stage" typical of most European lowland lakes and reservoirs, with roach and common bream together contributing $>50 \%$ of fish stock abundance (Kubečka, 1993). Some authors also include perch within the list of abundant littoral fish in lowland European lentic systems (e.g. Lewin et al., 2004; Järvalt et al., 2005; Brosse et al., 2007; Ř́ha et al., 2009) while others include rudd Scardinius erythrophthalmus (e.g. Irz et al., 2002; Jeppesen et al., 2006). Perch abundance varied between 5 and $26 \%$ at our reservoirs and rudd abundance between 2 and $12 \%$, with lowest levels at the small eutrophic Bojkovice reservoir and highest at the larger cleaner Landštejn reservoir. In addition to eutrophic status, species abundance (e.g. ruffe Gymnocephalus cernua; max. abundance $7 \%$ at Nová Říše) will depend on local geography or the physical characteristics of the system (Jeppesen et al., 2006; Blabolil et al., 2014). Rudd, for example, require aquatic macrophytes for nutrition and successful breeding and these were most abundant at Landštejn.

Decades of excessive loading with nitrogen and phosphorus, particularly in densely populated

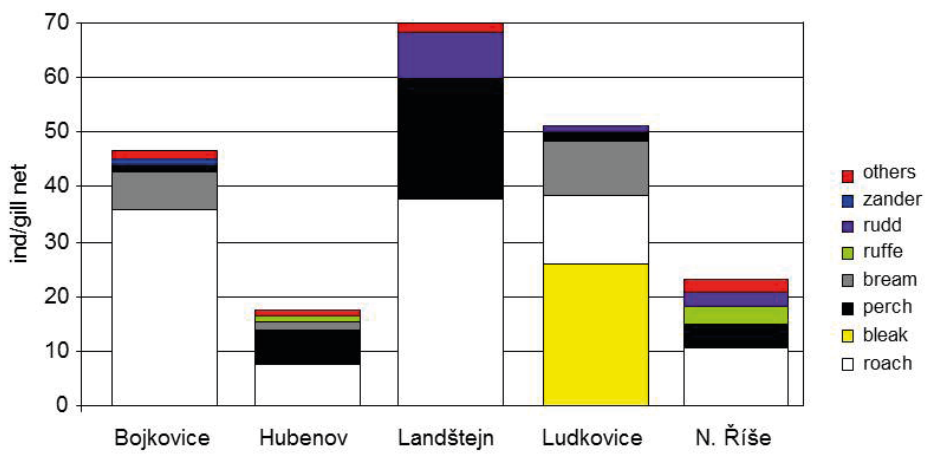

1: Abundance (catch per unit effort; ind/gill net) of fish species caught with gill nets at five drinking water reservoirs in 2016.

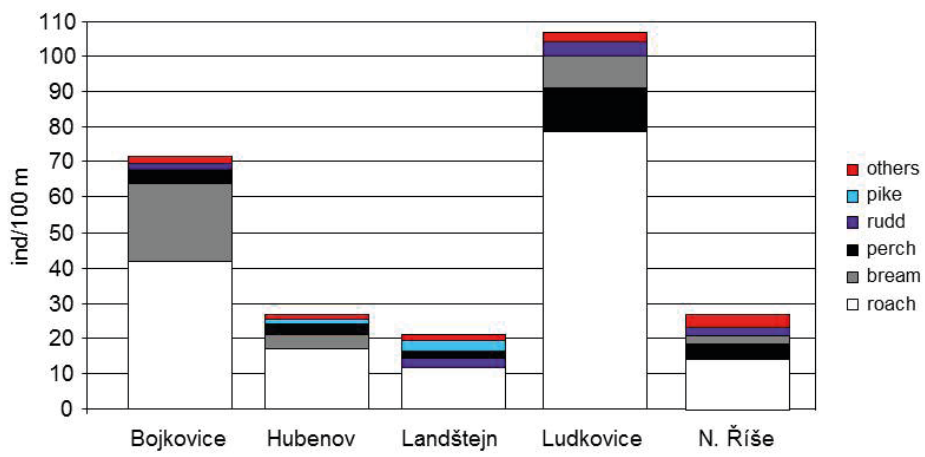

2: Abundance (catch per unit effort; ind/100 m) of fish species caught using electrofishing at five drinking water reservoirs in 2016. 
or intensively cultivated areas, has had a strong impact on the eutrophic status of many lakes and reservoirs in Czechia. Such inputs create ideal conditions for phytoplankton production, resulting in increased turbidity, decreased oxygen availability and decreased biological diversity. One method for shifting eutrophic lakes from a turbid phytoplankton-dominated state to a clearwater macrophyte-dominated state involves the biomanipulation (e.g. removal) of fish stocks (see Hansson, 1998; Lammens et al., 2002). Roach and common bream are usually the main targets of such measures in northern European shallow temperate lakes (Lathrop et al., 2002; Mehner et al., 2002; Van de Bund and Van Donk, 2002; Søndergaad et al., 2008) as they not only feed on zooplankton (which feed on phytoplankton) but also disturb the sediment in their search for sediment-dwelling invertebrates (Boll et al., 2012; Adámek and Maršálek, 2013). In addition, the density and biomass of predators, such as pike, zander, wells or asp may be artificially increased in order to reduce numbers of small planktivorous fish (Lathrop et al., 2002; Skov and Nilsson, 2007; Vašek et al., 2013). Other than supportive stocking of predatory species (mainly pike, zander, asp and wells), no other biomanipulation activities (e.g. large-scale removal of cyprinids) have been undertaken in the reservoirs in this study.

Increasing the density and biomass of piscivorous fish as a means of indirectly reducing smaller planktivorous fish has been applied in a number of previous biomanipulation projects (e.g. Lathrop et al., 2002; Skov et al., 2002; Mehner, 2010; Vašek et al., 2013). However, previous biomanipulation projects (e.g. Benndorf, 1990; Seda et al., 2000; Benndorf et al., 2002) have shown that stratified eutrophic lakes show no reduction in planktivorous species (and subsequent reductions in algal blooms) following piscivore enhancement if phosphorous loading remains high. In fact, Benndorf et al. (2002) suggested that biomanipulation through increased stocking of predators is not applicable in reservoirs with a total annual phosphorous loading exceeding 0.8 g. $\mathrm{m}^{-2}$ or a concentration of $50 \mathrm{mg} \cdot \mathrm{m}^{-3}$ (Jeppesen and Sammalkorpi, 2002). In both Ludkovice and Bojkovice, the annual phosphorous loading presently ranges between 2.1 and 4.4 g.m ${ }^{-2}$, suggesting that conditions at these reservoirs are still far from ideal for the control of planktivorous species by piscivore stocking.

In highly productive eutrophic reservoirs (such as Bojkovice and Ludkovice), the proportion of piscivorous fish is normally low (Jeppesen et al., 2000; Søndergaard et al., 2005); hence, enhancement and maintenance of these species at levels suitable for biomanipulation requires intense stocking (Vašek et al., 2013). Mehner et al. (2004) recommended that piscivores needed to represent a $30 \%$ proportion of total fish biomass in order to efficiently control recruitment of small planktivorous fish. The F/C biomass ratio between non-predatory and predatory fish in these reservoirs indicated an extremely high abundance of predatory species (Holčík and Hensel,

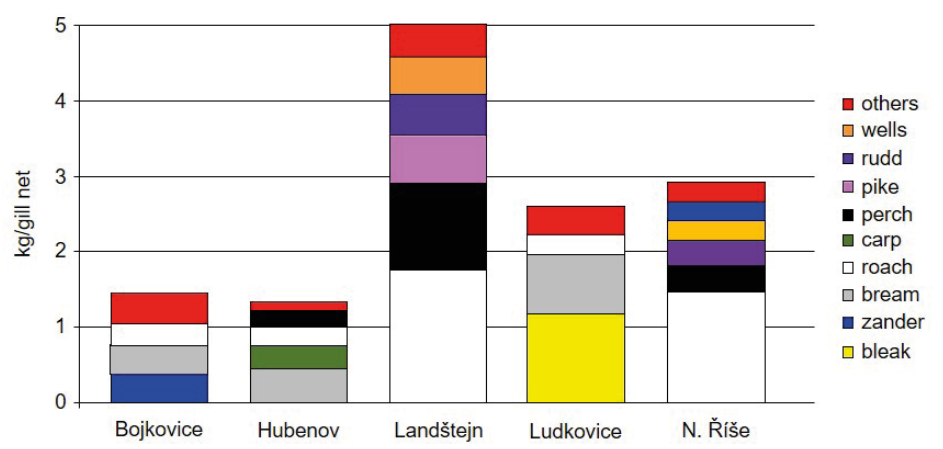

3: Biomass (catch per unit effort; kg/gill net) for fish species caught using gill nets at five drinking water reservoirs in 2016.

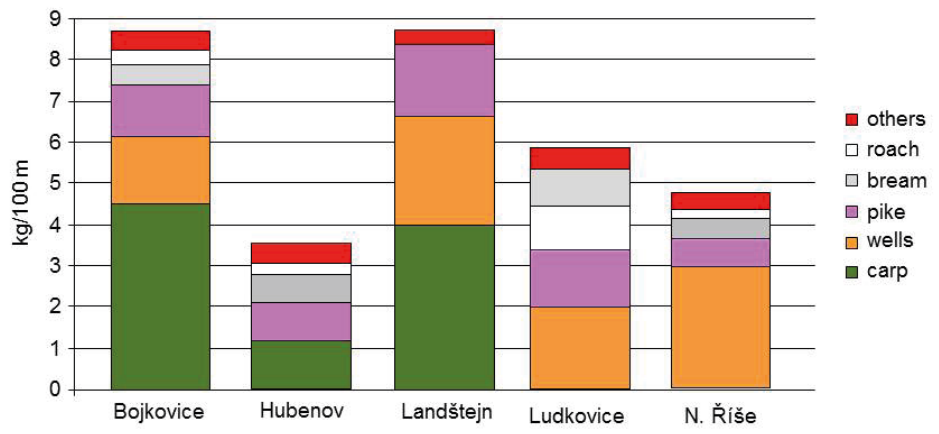

4: Biomass (catch per unit effort; kg/100 m) of fish species caught using electrofishing at five drinking water reservoirs in 2016. 
1972). In the reservoirs in this study, predatory species (not including perch) comprised between $24-59 \%$ of biomass (Fig. 6), i.e. close to or above that required. Note, however, that the greater part of the biomass in each case comprised large pike and wells sampled along the shoreline by electrofishing (Fig. 4; Tab. II). Littoral electrofishing is a much more efficient method for sampling such species than the standard European gillnet methodology presently used (Argillier et al., 2013) and there is little doubt that predatory species are heavily underestimated when using gillnets alone. While pike and wells appear to have been successfully supported by stocking in previous years, stocking of zander and asp has been less successful, with abundance and biomass remaining so low in Landštejn, for example, that none were caught at all, despite intensive stocking (especially zander). In this case, it is possible that the abundant perch population impacted on the survival of stocked juveniles of predatory species.

In Czech reservoirs, larger/older predatory fish tend to be a rarity as such fish are usually removed by anglers in recreational reservoirs, or removed illegally in those reservoirs where angling is prohibited (Vašek et al., 2013). In the five reservoirs in this study, predator stocking appears to have been generally successful as not only is there a complete ban on angling (especially for predatory/game species) as the reservoirs are designated for drinking water supply but also there is a much reduced likelihood of illegal fishing in small, well-controlled reservoirs such as Bojkovice and Ludkovice, or in reservoirs far from settlements, such as Hubenov, Landštejn or Nová Říše. Owing to the general low presence of smaller/younger predators in the catch, it remains uncertain whether natural reproduction has played any significant role in maintaining the present stock of predators. While it is impossible to say for certain based on this pilot-study, the low abundance and high biomass of predatory species implies a predominance of large fish, suggesting that stocking may be playing the major role.

Obtaining representative results when assessing fish assemblages can be difficult. Ideally, samples need to be taken from all available habitats (e.g. littoral, pelagic, vegetation, open water, woody debris, rocks), as different fish species, sizes or age groups will favour different habitats, which will require different sampling methods and equipment (Kubečka et al., 2009). Complex monitoring programmes such as these are expensive and time consuming; hence, most European countries tend to use Nordic multimesh gillnets as a representative sampling method (Argillier et al., 2013). As our results show,

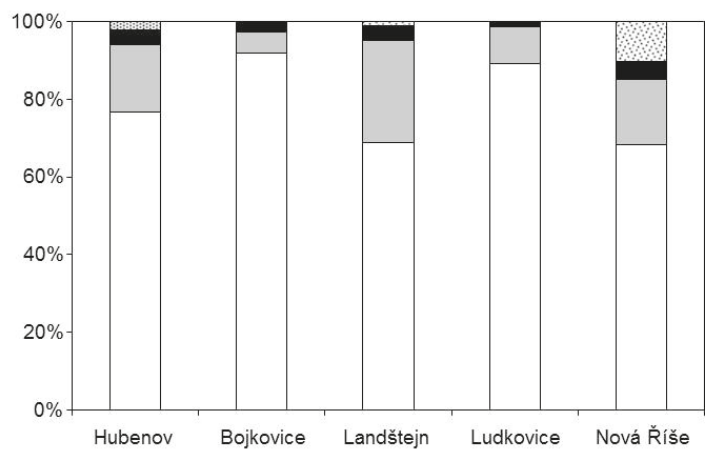

5: Relative abundance (\%) of cyprinids, predators and perch caught at five drinking water reservoirs monitored in 2016 $($ white $=$ cyprinids, grey $=$ perch, black $=$ predators, dots $=$ other species $)$.

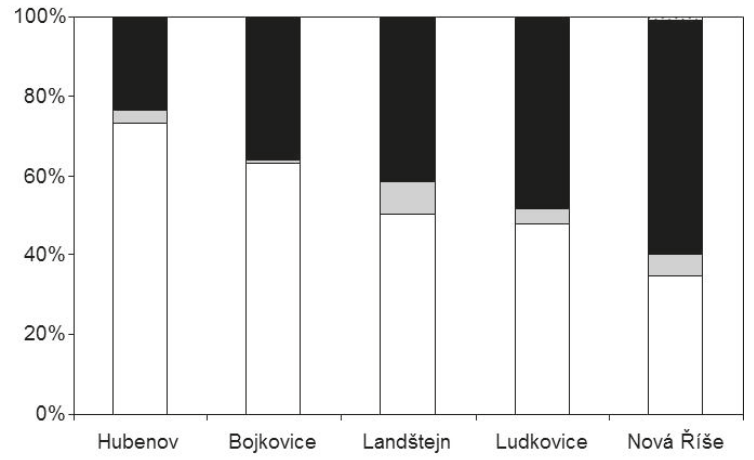

6: Relative biomass (\%) of cyprinids, predators and perch caught at five drinking water reservoirs in 2016 (white $=$ cyprinids, grey $=$ perch, black $=$ predators, dots $=$ other species $)$. 
however, different methods (e.g. pelagic gill netting and littoral electrofishing), when applied alone, produce very different results. Compared to gill netting, electrofishing along the bank tended to underestimate pelagic species such as bleak and benthic species such as ruffe; on the other hand, electrofishing was more efficient at sampling carp, pike and wells (Figs. 3, 4). In doing so, electrofishing significantly increased the overall biomass of large predatory species and carp in the pooled sample (Fig. 4). As an example, a previous study at Nová Říše using gill nets (Blabolil et al., 2014) produced abundance results that largely agree with our own study, with an assemblage dominated by roach, followed by perch and rudd. The addition of electrofishing biomass data, however, shifted dominance to wells, followed by roach, pike and bream.

\section{CONCLUSION}

Between May and July 2016, we examined the fish communities of five Moravian reservoirs (Ludkovice, Bojkovice, Hubenov, Nová Říše and Landštejn). Nineteen fish species and one hybrid were recorded, with roach dominating overall by abundance, but carp, pike and wels dominating by biomass in electrofishing samples. Predatory species represented up to $60 \%$ of biomass, with an F/C index ranging from $0.5-3$, implying a high abundance of predators. Electrofishing tended to underestimate the abundance of bleak and ruffe, while gill nets underestimated the biomass of predatory species. Overall, gill netting alone appears inadequate for gaining a true picture of the fish community in reservoirs. As successful fish stock biomanipulation requires accurate data on the biomass of predators present, sampling by gill nets alone may provide unreliable results, with implications for fish stock management and water quality. In order to ensure the success of biomanipulation efforts in future, therefore, we suggest that future studies on reservoir fish stocks combine littoral electrofishing and gill netting and that, where necessary, the eutrophic status of the reservoir is addressed and improved.

\section{Acknowledgements}

This study was supported through the NAZV project QJ1620240 (Application of "top-down" biomanipulation to reduce eutrophication caused by agriculture in reservoirs). The authors are grateful to the officials and managers of the River Morava Authority s.p. (especially I. Bazala, P. Dobrovolný and R. Konstanz) for allowing access to their properties and for providing assistance in the field. Finally, we would like to thank all our colleagues who helped with the fieldwork.

\section{REFERENCES}

ADÁMEK, Z. and MARŠÁLEK, B. 2013. Bioturbation of sediments by benthic macroinvertebrates and fish and its implication for pond ecosystems: a review. Aquac. Int., 21(1): 1-17.

ARGILlIER, C., CAUSSE’', S., GEVREY, M., PÉDRO, S., DE BORTOLI, J., BRUCET, S., EMMRICH, M., JEPPESEN, E., LAURIDSEN, T., MEHNER, T., OLIN, M., RASK, M., VOLTA, P., WINFIELD, I.J., KELLY, F., KRAUSE, T., PALM, A. and HOLMGREN, K. 2013. Development of a fish-based index to assess the eutrophication status of European lakes. Hydrobiologia, 704(1): 193-211.

BENNDORF, J., BÖING, W., KOOP, J. and NEUBAUER, I. 2002. Top-down control of phytoplankton: the role of time scale, lake depth and trophic state. Freshw. Biol., 47: 2282-2295.

BENNDORF, J. 1990. Conditions for effective biomanipulation; conclusions derived from whole-lake experiments in Europe. Hydrobiologia, 200/201: 187-203.

BLABOLIL, P., ŘÍHA, M., PETERKA, J., PRCHALOVÁ, M., VAŠEK, M., JU゚ZA, T., ČECH, M., DRAŠTÍK, V., KRATOCHVÍL, M., MUŠKA, M., TUŠER, M., FROUZOVÁ, J., RICARD, D., ŠMEJKAL, M., VEJŘÍK, L., DURAS, J., MATĚNA, J., BOROVEC, J. and KUBEČKA, J. 2014. The current status of Czech reservoirs based on fish community composition [in Czech: Současný stav nádrží v České republice z hlediska složení rybích obsádek]. Vodníhospodáriství, 9: 5-11.

BOLL, T., Johansson, L.S., Lauridsen, T. L., Landkildehus, F., Davidson, T. A., Søndergaard, M., Andersen, F. Ø. and Jeppesn, E. 2012. Changes in benthic macroinvertebrate abundance and lake isotope (C, N) signals following biomanipulation: an 18-year study in shallow Lake Vaeng, Denmark. Hydrobiologia, 686(1): 135-145.

BROSSE, S., GROSSMAN, G. D. and LEK, S. 2007. Fish assemblage patterns in the littoral zone of a European reservoir. Freshw. Biol., 52: 448-458.

HANSSON, L. A. 1998. Biomanipulation as an application of food-chain theory: constraints, synthesis, and recommendations for temperate lakes. Ecosystems, 1(6): 558-574.

HOLČÍK, J. and HENSEL, K. 1972. Ichthyologic handbook [in Slovak: Ichtyologická príručka]. $1^{\text {st }}$ Edition. Bratislava: Obzor.

Irz, P., Laurent, A., Messad, S., Pronier, O. and Argillier, C. 2002. Influence of site characteristics on fish community patterns in French reservoirs. Ecology of Freshwater Fish, 11(2): 123-136. 
JÄRVALT, A., KRAUSE, T. and PALM, A. 2005. Diel migration and spatial distribution of fish in a small stratified lake. Hydrobiologia, 547(1): 197-203.

JEPPESEN, E., PEDER JENSEN, J., SØNDERGAARD, M., LAURIDSEN, T. and LANDKILDEHUS, F. 2000. Trophic structure, species richness and biodiversity in Danish lakes: changes along a phosphorus gradient. Freshw. Biol., 45: 201-218.

JEPPESEN, E. and Sammalkorpi, I. 2002. Lakes. In: Perrow, M. and Davy, T. (Eds.). Handbook of Ecological Restoration. Volume 2: Restoration practice. Cambridge, UK: Cambridge University Press.

JEPPESEN, E., PEKCAN-HEKIM, Z., LAURIDSEN, T. L., SØNDERGAARD, M. and JENSEN, J. P. 2006. Habitat distribution of fish in late summer: changes along a nutrient gradient in Danish lakes. Ecology of Freshwater Fish, 15: 180-190.

KUBEČKA, J. 1993. Succession of fish communities in reservoirs of Central and Eastern Europe. In: Straškraba, M., Tundisi, J.G. and Duncan, A. (Eds.). Comparative Reservoir Limnology and Water Quality Management. Amsterdam: Kluwer Academic Publishers Group.

KUBEČKA, J., HOHAUSOVÁ, E., MATĚNA, J., PETERKA, J., AMARASINGHE, U.S., BONAR, S.A., HATELEY, J., HICKLEY, P., SUURONEN, P., TERESCHENKO, V., WELCOMME, R. and WINFIELD, I. J. 2009. The true picture of a lake or reservoir fish stock: A review of needs and progress. Fisheries Research, 96(1): 1-5.

KUBEČKA, J., FROUZOVÁ, J., JƯZA, T., KRATOCHVÍL, M., PRCHALOVÁ, M. and ŘíHA, M. 2010. Metodika monitorování rybích společenstev nádrži a jezer. České Budějovice: Biologické centrum AV ČR, v.v.i. Hydrobiologický ústav.

LAMMENS, E. H. R. R., VAN NES, E. H. and MOOIJ, W. M. 2002. Differences in the exploitation of bream in three shallow lake systems and their relation water quality. Freshw. Biol., 47: 2435-2442.

LATHROP, R. C., JOHNSON, B. M., JOHNSON, T. B., VOGELSANG, M. T., CARPENTER, S. R., HRABIC, T. R., KITCHELL, J. F., MAGNUSON, J. J., RUDSTAM, L. G. and STEWART, R. S. 2002. Stocking piscivores to improve fishing and water clarity: a synthesis of the Lake Mendota biomanipulation project. Freshw. Biol., 47(12): 2410-2424.

LEWIN, W. C., OKUN, N. and MEHNER, T. 2004. Determinants of the distribution of juvenile fish in the littoral area of a shallow lake. Freshw. Biol., 49(4): 410-424.

MEHNER, T. 2010. No empirical evidence for community-wide top-down control of prey fish density and size by fish predators in lakes. Limnology and Oceanography, 55(1): 203-213.

MEHNER, T., ARLINGHAUS, R., BERG, S., DÖRNER, H., JACOBSEN, L., KASPRZAK, P., KOSCHEL, R., SCHULZE, T., SKOV, C., WOLTER, C. and WYSUJACK, K. 2004. How to link biomanipulation and sustainable fisheries management: a step-by-step guideline for lakes of the European temperate zone. Fisheries Management and Ecology, 11(3 + 4): 261-275.

MEHNER, T., BENNDORF, J., KASPRZAK, P. and KOSCHEL, R. 2002: Biomanipulation of lake ecosystems: successful applications and expanding complexity in the underlying science. Freshw. Biol., 47: $2453-2465$.

PIVNIČKA, K. 1992. The Klíčava Reservoir, Czechoslovakia - a 30 year study of the fish community. Fisheries Research, 14(1): 1-20.

PRCHALOVA, M., KUBEČKA, J., ŘÍHA, M., MRKVIČKA, T., VAŠEK, M., JŮZA, T., KRATOCHVÍL, M., PETERKA, J., DARŠTÍK, V. and KŘǏ̌EK, J. 2009. Size selectivity of standardized multimesh gillnets in sampling coarse European species. Fisheries Research, 96: 51-57.

ŘíHA, M., KUBEČKA, J., VAŠEK, M., SEDA, J., MRKVIČKA, T., PRCHALOVÁ, M., MATĚNA, J., HLADÍK, M., ČECH, M., DRAŠTÍK, V., FROUZOVÁ, J., HOHAUSOVÁ, E., JAROLÍM, O., JŮZA, T., KRATOCHVÍL, M., PETERKA, J. and TUŠER, M. 2009. Long-term development of fish populations in the Římov Reservoir. Fisheries Management and Ecology, 16: 121-129.

SEDA, J., HEJZLAR, J. and KUBEČKA, J. 2000. Trophic structure of nine Czech reservoirs regularly stocked with piscivorous fish. Hydrobiologia, 429(1-3): 141-149.

SKOV, C. and NILSSON, P. A. 2007. Evaluating stocking of YOY pike Esox lucius as a tool in the restoration of shallow lakes. Freshw. Biol., 52(9): 1834-1845.

SKOV, C., PERROW, M. R., BERG, S. and SKOVGAARD, H. 2002. Changes in the fish community and water quality during seven years of stocking piscivorous fish in a shallow lake. Freshw. Biol., 47(12): 2388-2400.

SØNDERGAARD, M., JEPPESEN, E., PEDER JENSEN, J. and LILDAL AMSINCK, S. 2005. Water Framework Directive: ecological classification of Danish lakes. J. Applied Ecol., 42: 616-629.

SØNDERGAARD, M., LIBORIUSSEN, L., REDERSEN, A. R. and JEPPESEN, E. 2008. Lake restoration by fish removal: short- and long-term effects in 36 Danish Lakes. Ecosystems, 11: 1291-1305.

VAN DE BUND, W.J. and VAN DONK, E. 2002. Short-term and long-term effects of zooplanktivorous fish removal in a shallow lake: a synthesis of 15 years of data from Lake Zwemlust. Freshw. Biol., 47: 2380-2387.

VAŠEK, M., KUBEČKA, J., MATĚNA, J. and SEDA, J. 2006. Distribution and diet of 0+ fish within a canyonshaped European reservoir in late summer. Internat. Rev. Hydrobiol., 91: 178-194.

VAŠEK, M., PRCHALOVÁ, M., PETERKA, J., KETELAARS, H.A.M., WAGENVOORT, A.J., ČECH, M., DRAŠTÍK, V., ŘÍHA, M., JŮZA, T., KRATOCHVÍL, M., MRKVIČKA, T., BLABOLIL, P., BOUKAL, D. S. and 
KUBEČKA, J. 2013. The utility of predatory fish in biomanipulation of deep reservoir. Ecological Engineering, 52: 104-111.

VOSTRADOVSKÝ, J. and TICHÝ, J. 1999. History of fish stock development, fishery management and research on the Lipno reservoir. Bulletin VURH Vodñany, 35: 48-65. 